\title{
FGFR2 Gene Mutation
}

National Cancer Institute

\section{Source}

National Cancer Institute. FGFR2 Gene Mutation. NCI Thesaurus. Code C107579.

A change in the nucleotide sequence of the FGFR2 gene. 